\title{
Smoke inhalation injury during enclosed-space fires: an update*
}

\author{
Lesão por inalação de fumaça em ambientes \\ fechados: uma atualização
}

\author{
Ana Carolina Peçanha Antonio, Priscylla Souza Castro, Luiz Octavio Freire
}

\begin{abstract}
In view of the tragic fire at a nightclub in the city of Santa Maria, Brazil, which culminated in the sudden death of 232 young people, we decided to review the literature regarding smoke inhalation injury caused by enclosed-space fires, which can be divided into direct thermal damage, carbon monoxide poisoning, and cyanide poisoning. Such injuries often call for immediate orotracheal intubation, either due to acute airway obstruction or due to a reduced level of consciousness. The diagnosis and the severity of the thermal injury can be determined by fiberoptic bronchoscopy. The levels of gases and gas by-products in the bloodstream should be assessed as rapidly as possible, even while still at the scene of the incident. First responders can also treat carbon monoxide poisoning, with immediate administration of oxygen at 100\%, as well as cyanide poisoning, with oxygen therapy and hydroxocobalamin injection.
\end{abstract}

Keywords: Smoke inhalation injury; Carbon monoxide; Cyanides.

\section{Resumo}

Aproveita-se o trágico incêndio ocorrido em uma boate na cidade de Santa Maria, RS, que culminou na morte imediata de 232 jovens, para revisarmos a literatura com relação à lesão por inalação de fumaça em ambientes fechados, que pode ser dividida em dano térmico direito, intoxicação por monóxido de carbono e intoxicação por cianeto. Essas condições frequentemente levam à necessidade de intubação orotraqueal imediata, seja por obstrução aguda de vias aéreas, seja por depressão do nível de consciência. 0 diagnóstico e a gravidade da injúria térmica podem ser determinados pela fibrobroncoscopia. Quanto aos envenenamentos, a dosagem dos gases ou de seus subprodutos na corrente sanguínea é possível e deve ser realizada ainda na cena do incidente. Da mesma maneira, o tratamento da intoxicação por monóxido de carbono consiste na administração imediata de oxigênio a 100\%, enquanto o da intoxicação por cianeto consiste em oxigenoterapia e hidroxicobalamina injetável como antídoto.

Descritores: Lesão por inalação de fumaça; Monóxido de carbono; Cianetos.

\section{Introduction}

In the early hours of January 27, 2013, 232 young adult victims died immediately during the fire at a nightclub in the city of Santa Maria, Brazil. Of the survivors, 88 were admitted to the ICU with severe smoke inhalation injury (SII) and varying percentages of total body surface area (TBSA) burned, as well as with other injuries, most of which were of moderate severity. This was the second largest fire death toll in the history of Brazil. The health care facilities in the state of Rio Grande do Sul joined forces in order to optimize victim assistance, meeting with international authorities periodically in order to exchange experiences. In view of these facts, it is necessary to review and update the literature regarding adults with SIl caused by enclosedspace fires, including direct thermal damage to the airways, hydrogen cyanide ( $\mathrm{HCN})$ poisoning, and carbon monoxide (CO) poisoning.

In a model to estimate burn-related mortality, S1l, together with age $>60$ years and $>40 \%$ TBSA burned, is an independent factor for mortality. In the presence of only one of those factors, the burn mortality rate is $3 \%$, increasing to

* Study carried out at the Hospital Mãe de Deus, Porto Alegre, Brazil.

Correspondence to: Ana Carolina Peçanha. Rua Ari Marinho, 11/210, CEP 90520-300, Porto Alegre, RS, Brasil.

Tel. 5551 8442-8820. E-mail: ana.carolina.pecanha@me.com

Financial support: None.

Submitted: 26 February 2013. Accepted, after review: 25 April 2013. 
$33 \%$ and $90 \%$, respectively, when two and all of those factors are present. ${ }^{(1)}$

It is impossible to predict the pathophysiological interactions of all toxins produced by smoke, especially if we consider the wide variety of pyrolysis components and the unpredictable rate of by-product formation, depending on the temperature, area, and composition of the environment. During a fire, the concentration of oxygen $\left(\mathrm{O}_{2}\right)$ typically drops to $10-15 \%$, at which point death from asphyxia occurs. ${ }^{(2,3)}$ Between $60 \%$ and $80 \%$ of all sudden deaths occurring at the scene of a fire are attributed to smoke inhalation. ${ }^{(4)}$ The classic scenario is an enclosedspace fire, with loss of consciousness in the presence of facial burns or large TBSA burns. ${ }^{(5)}$

Didactically, Slls can be classified into three types: 1) upper airway thermal injury involving the mouth, oropharynx, and larynx; 2) lower airway and parenchymal injury caused by chemicals and particulate matter originating from smoke; and 3) metabolic asphyxiation, whereby certain smoke constituents impede tissue $\mathrm{O}_{2}$ delivery, tissue $\mathrm{O}_{2}$ consumption, or both. ${ }^{(5)}$ The immediate management of Sll victims should focus primarily on the ABCDE of trauma. ${ }^{(3)}$

For thermal injury itself, we searched the Medline database using the following search strategy: "Smoke Inhalation Injury"(Mesh) AND (“2003/02/14”(PDat) : “2013/02/10”(PDat) AND "humans"(MeSH Terms) AND English(lang) AND "adult"(MeSH Terms). A total of 127 references were retrieved. After having read the titles and abstracts, we excluded 97 references, because they were outside the scope of the present review. For CO poisoning, we used the following strategy: "Carbon Monoxide Poisoning”(Mesh) AND "Burns”(Mesh) AND (“2003/02/28”(PDat) : “2013/02/24”(PDat) AND "humans"(MeSH Terms) AND English(lang). A total of 34 references were retrieved. After having read the abstracts, we excluded 28 of those references because the settings of the studies in question were other than fires. For $\mathrm{HCN}$ poisoning, we used the following search strategy: (english(Language) AND ("2001”(PDAT) : “2013”(PDAT))) AND ((“burns”(MeSH Terms) OR "burns”(All Fields)) AND (“cyanides”(MeSH Terms) OR “cyanides”(All Fields) OR “cyanide”(All Fields)) AND ("poisoning”(Subheading) OR "poisoning”(All Fields) OR “poisoning”(MeSH Terms)) AND ("therapy"(Subheading) OR "therapy"(All Fields) OR “treatment”(All Fields) OR “therapeutics”(MeSH
Terms) OR “therapeutics”(All Fields))). A total of 24 references were retrieved. After having read the abstracts, we excluded 8 of those references because the studies in question did not involve adult burn patients in a hospital setting. Subsequently, we included some specific review articles on the topics of interest.

\section{Airway inhalation injury}

Upper airway inhalation injury resulting in obstruction within the first $12 \mathrm{~h}$ after the incident is caused by direct thermal damage, chemical irritation, or both. The resulting pathophysiological changes are not due to the burn per se; the smoke itself, which is far more capable of carrying heat than is dry air, can overwhelm the ability of the upper airways to dissipate extreme heat. Nor is the carbonaceous material present in the smoke able to damage the lung parenchyma, although it can serve as a vehicle for other damaging agents.

Up to one third of all Sll victims can present with acute upper airway obstruction. ${ }^{(6)}$ Direct thermal injury to the face and airways is always indicative of a difficult airway; however, prophylactic establishment of a definitive airway is not mandatory in such cases. ldeally, all victims suspected of having inhaled smoke should undergo fiberoptic bronchoscopy in order to determine whether the laryngeal edema is severe enough and whether there is injury below the glottis. A retrospective study conducted in a burn referral center evaluated 41 patients, 8 of whom underwent orotracheal intubation (OTI), and showed a high correlation between the need for OTl and the presence of facial burns and soot in the oral cavity but no correlation between the need for $\mathrm{OTl}$ and the classic signs and symptoms, i.e., stridor, dysphonia, dysphagia, and sialorrhea. ${ }^{(7)}$ Nevertheless, prophylactic OT1 is recommended for all patients with extensive burns, i.e., those with more than 40\% TBSA burned. ${ }^{(5)}$

Fiberoptic bronchoscopy is the gold standard for the diagnosis of airway inhalation injury. In addition, fiberoptic bronchoscopy is often used for airway hygiene, removing particulate matter, mucus plugging obstructing bronchi, and the large quantity of inflammatory secretion that forms because of cellular necrosis (Figure 1). ${ }^{(5,6)}$ Furthermore, fiberoptic bronchoscopy can predict the evolution of patients from a respiratory standpoint. Bronchoscopic grading through the abbreviated injury score (AIS), whereby thermal 
injury to the airway is classified as 0 (no injury), 1 (mild injury), 2 (moderate injury), 3 (severe injury), or 4 (massive injury), was associated with decreased $\mathrm{PaO}_{2} / \mathrm{FiO}_{2}$ within the first $24 \mathrm{~h}$ after ICU admission in a retrospective cohort of 32 patients with extensive burns. ${ }^{(8)}$ Another study showed that, in patients with extensive burns, a higher AIS at admission correlated with a longer duration of mechanical ventilation (a median of 3 days for grade 0 and of 23 days for grade 4), a trend toward a greater frequency of tracheostomy, and a longer ICU stay. ${ }^{(9)}$ A retrospective cohort study showed an absolute reduction of $27 \%$ in survival in patients with an AIS of 2-4 in comparison with those with an AIS of 0 or $1 .^{(10)}$

Classically, imaging tests such as chest $\mathrm{X}$-rays and CT scans have little or no value in the diagnosis of S11. ${ }^{(5,6)} \mathrm{A}$ retrospective analysis of 44 patients admitted to a burn referral center showed that chest CT scans taken within the first $24 \mathrm{~h}$ after admission have prognostic value in predicting the composite outcome of pneumonia, ARDS, and death. ${ }^{(11)}$

Serial repetition of fiberoptic bronchoscopy after the diagnosis has been established remains controversial among experts. In the literature, there are no prospective or intervention studies specifically examining this issue. In the USA, a study of 624 patients with S1l receiving different treatment regimens showed no conclusive (statistically significant) results regarding the aggressive use of fiberoptic bronchoscopy, although there seemed to be a slight trend toward shorter hospital stays in those who underwent more than one procedure during their hospital stays. ${ }^{(12)}$

Appropriate fluid resuscitation is the cornerstone of treatment of patients with extensive burns. ${ }^{(13)}$ However, in the literature, conflicting opinions exist regarding the presence of concomitant S11, which are due to the fear that significant worsening of lung compliance might lead to irreversible hypoxemia. ${ }^{(5)}$ Nevertheless, a retrospective cohort study showed that the presence of S1l increases the need for fluid resuscitation by approximately 34\%.(14) One group of authors found no correlation between increased fluid requirements and the AIS, i.e., the severity of the initial injury. ${ }^{(10)}$

The management of patients with thermal injury to the airways is basically supportive. As
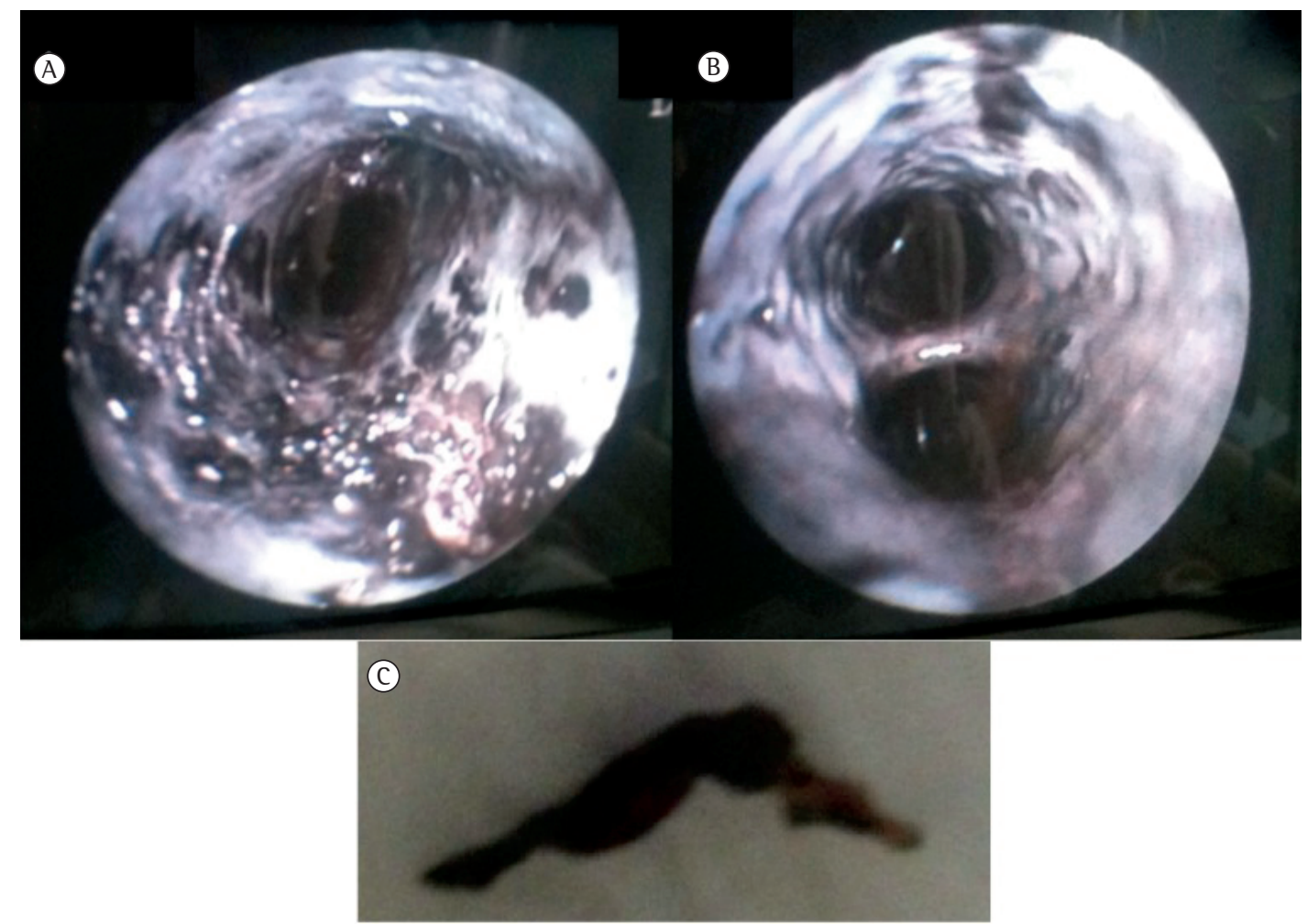

Figure 1 - $\ln A$ and $B$, severe thermal injury in a patient with extensive burns. In C, particulate matter extracted from the airway. 
in any other context, a protective ventilatory strategy is recommended, with a tidal volume of 4-8 $\mathrm{mL} / \mathrm{kg}$ of predicted weight and a plateau airway pressure of less than $30 \mathrm{cmH}_{2} \mathrm{O}$. No other strategy is recommended..$^{(13)}$

When high-frequency oscillatory ventilation was used as a rescue therapy for patients who developed ARDS after extensive burns, the group of patients with airway inhalation injury showed a poor response, showing prohibitive levels of hypercapnia, possibly due to the impossibility of nebulizer use. ${ }^{(15)} \mathrm{A}$ randomized clinical trial comparing protective ventilation and highfrequency oscillatory ventilation in a sample of 62 patients with extensive burns, in whom the prevalence of S1I was 37\%, showed no differences between the two groups regarding the primary outcome measure "number of ventilator-free days"; however, the need for rescue ventilation was more common in the group of patients receiving low tidal volume ventilation. ${ }^{(16)} \mathrm{A}$ quasi-experimental trial including 18 patients with severe ARDS (12 of whom had S1I) showed that prone positioning improves oxygenation. ${ }^{(17)}$ Finally, a meta-analysis of the use of extracorporeal membrane oxygenation in burn patients with varying degrees of airway involvement concluded that the current literature is insufficient to support or oppose the use of the technique in such patients. ${ }^{(18)}$

In a case series of 37 patients with S1l, noninvasive mechanical ventilation was used as initial ventilatory support; 6 patients $(16.2 \%)$ required emergency 0T1, and another 16 (43.7\%) subsequently required invasive mechanical ventilation over the course of 29 days of follow-up. The mortality rate in the case series was $13.5 \%$. The authors concluded that noninvasive ventilation can be used as initial ventilatory support in patients with SIl provided that they are conscious and hemodynamically stable. ${ }^{(19)}$

Thermal injury triggers an intense inflammatory reaction in the airways, with activation of procoagulant factors and release of oxygen free radicals. This explains the close association between thermal injury and the development of ARDS. One of the first studies to evaluate the therapeutic role of inhaled heparin and $\mathrm{N}$-acetylcysteine in adults retrospectively analyzed 62 patients who had received the combination therapy during the first $72 \mathrm{~h}$ of admission and concluded that, although there was an improvement in the $\mathrm{PaO}_{2} /$ $\mathrm{FiO}_{2}$ ratio, the therapy had no long-lasting effect and did not affect clinical outcomes, which did not differ between the treated and untreated groups. ${ }^{(20)}$ However, a population-based nested case-control study conducted in the following year showed significant improvements in hypoxemia and lung compliance in the group receiving the combination therapy, as well as showing a significant reduction in mortality even after 150 days of follow-up, the number needed to treat being 3. ${ }^{(21)} A$ systematic review of 11 experimental studies and 3 clinical studies recommended the use of nebulized heparin in patients with thermal injury to the airways, on the basis of improved survival and a higher number of ventilator-free days. ${ }^{(22)}$

Pneumonia is one of the most common complications of S1l, its incidence being approximately $30 \%,{ }^{(23-25)}$ particularly in patients over 60 years of age, those with more than 20\% TBSA burned, those with an AIS above 3, and those with $\mathrm{CO}$ poisoning and hypoxemia at presentation. ${ }^{(25)}$ Prevention and treatment strategies are similar to those employed in the management of nosocomial pneumonia.

As in any other critically ill patient, early extubation is recommended. The timing of tracheostomy has yet to be well established; however, some authors have suggested that tracheostomy be performed within up to 7 days after initiation of mechanical ventilation. ${ }^{(26)}$

long-term follow-up of 52 patients who were victims of a fire in a subway station in Korea in 2003 showed significant improvements in FVC and FEV 1 within 3 months after the incident and complete remission in the following 3 months, the small group of patients receiving corticosteroid therapy having shown no improvement. ${ }^{(27)}$

\section{CO poisoning}

It is known that CO is an asphyxiant, colorless, odorless, tasteless, and non-irritating gas, ${ }^{(28)}$ which is produced by the incomplete combustion of hydrocarbons. ${ }^{(29,30)} 1$ ts concentration in the atmosphere is generally less than $0.001 \% \cdot{ }^{(31)} \mathrm{A}$ CO concentration of only $1 \%$ is enough to cause serious injury because $\mathrm{CO}$ is rapidly absorbed by the pulmonary epithelium and has high affinity for hemoglobin, ${ }^{(30)}$ which can be 200-250 times higher than that of $\mathrm{O}_{2}{ }^{\left({ }^{(31)}\right.}$ Of all Sll-related deaths, CO poisoning accounts for $80 \%$, and most occur within the first $24 \mathrm{~h}$ after exposure. ${ }^{(32)}$ 
Carboxyhemoglobin (COHb) is an extremely stable complex, and $\mathrm{COHb}$ production decreases oxyhemoglobin saturation and shifts the hemoglobin dissociation curve to the left, reducing the release of $\mathrm{O}_{2}$ to tissues. ${ }^{(31,33)} \mathrm{ln}$ addition, competitive inhibition with the cytochrome oxidase complex, principally P-450, prevents the use of $\mathrm{O}_{2}$ to generate energy. ${ }^{(34)}$ Additional mechanisms include CO binding to myoglobin, impairing $\mathrm{O}_{2}$ storage in muscle, and brain lipid peroxidation. ${ }^{(35)}$ Brain lipid peroxidation after $\mathrm{CO}$ exposure is similar to post-ischemic reperfusion and is mediated by changes in cerebral blood flow and oxidative damage by free radicals. ${ }^{(33)}$

As is the case for most toxins, the extent of the injury caused by CO poisoning depends on the $\mathrm{CO}$ concentration, exposure duration, and comorbidities in the exposed individual. ${ }^{(35)}$ The clinical symptoms of $\mathrm{CO}$ poisoning are nonspecific and suggestive of many differential diagnoses. Patients can present with tachycardia and tachypnea as compensatory mechanisms for cellular hypoxia. Headache, nausea, and vomiting are common symptoms. Syncope, presyncope, and convulsions result from cerebral vasodilation and cellular hypoxia and can also cause brain edema. Angina, acute pulmonary edema, and arrhythmias can result from the increased cardiac output that follows. Patients with cardiovascular disease and those with lung disease can experience symptom exacerbation. The classic findings of cherry-red lips, cyanosis, and retinal hemorrhages are rare. ${ }^{(31)}$

Many exposed individuals show no acute signs of cerebral involvement; however, delayed neuropsychiatric sequelae have been described and can occur within 3-240 days after exposure. The estimated incidence is $10-30 \%$. Cognitive changes, personality changes, Parkinsonism, agnosia, apraxia, incontinence, dementia, and psychosis have been reported and can persist for one year or more. In such patients, cranial $\mathrm{CT}$ and magnetic resonance imaging can show characteristic changes, which include bilateral necrosis of the globus pallidus, cerebral cortex, hippocampus, or substantia nigra. ${ }^{(29,31,33)}$

The diagnosis of CO poisoning is based on a history of CO exposure and on consistent physical examination findings. ${ }^{(28)}$ It is possible to measure $\mathrm{COHb}$ levels by co-oximetry of a blood sample. ${ }^{(33)}$ Pulse oximetry cannot distinguish between $\mathrm{COHb}$ and oxyhemoglobin at the wavelengths that are commonly employed by most devices.
The severity of the symptoms appears to correlate better with exposure duration than with $\mathrm{COHb}$ levels. These values can be low or even undetectable depending on the time elapsed between exposure and measurement. ${ }^{(28,30,31)}$ The levels of $\mathrm{COHb}$ do not predict the degree of neurological sequelae. ${ }^{(28)}$ Nonsmokers rarely present with $\mathrm{COHb}$ levels above $1.5 \%$, whereas smokers can present with $\mathrm{COHb}$ levels as high as $5 \%$. Levels of $\mathrm{COHb}$ above $10-15 \%$ are consistent with $\mathrm{CO}$ poisoning. ${ }^{(33)}$

After the diagnosis of $\mathrm{CO}$ poisoning has been confirmed, electrocardiography is recommended. A more detailed assessment, with measurement of cardiac biomarkers, is warranted in patients with electrocardiographic changes, those with symptoms suggestive of myocardial ischemia, those over 65 years of age, and those with a history of or risk factors for heart disease. ${ }^{(29,36,37)}$

Most patients can be evaluated and treated as outpatients. Hospitalization should be considered for patients with severe poisoning, severe comorbidities, or associated injuries. ${ }^{(31)}$

The treatment of CO poisoning is based on $\mathrm{O}_{2}$ supplementation, ventilatory support, and cardiac monitoring. ${ }^{(29)}$ In cases of CO poisoning, $\mathrm{O}_{2}$ plays a role in increasing gas exchange reserve, reversing the effect of hypoxic gas inhalation, and in dissociating CO from its binding sites. ${ }^{(34)}$ Patients with $\mathrm{CO}$ poisoning should receive $\mathrm{O}_{2}$ therapy at high concentrations (ideally at 100\%) for $6-12 \mathrm{~h}$, because this reduces the half-life of $\mathrm{CO}$.

The mean half-life of $\mathrm{COHb}$ is $320 \mathrm{~min}$ in young healthy volunteers ventilated on room air. The administration of $\mathrm{O}_{2}$ at $100 \%$ and 1 atm reduces the half-life of $\mathrm{COHb}$ to $80.3 \mathrm{~min}$, whereas the administration of $\mathrm{O}_{2}$ at $3 \mathrm{~atm}$ reduces the half-life of $\mathrm{COHb}$ to 23.3 min. ${ }^{(29)}$ Hyperbaric $\mathrm{O}_{2}$ therapy (HBOT) is recommended by most toxicologists when $\mathrm{COHb}$ levels are higher than 25. 1deally, HBOT should be initiated within 6 $\mathrm{h}$ after $\mathrm{CO}$ exposure, and there is no proven benefit for patients receiving HBOT more than $12 \mathrm{~h}$ after $\mathrm{CO}$ exposure. However, HBOT is not widely available or risk-free. ${ }^{(29,31,33)}$ There are 7 randomized clinical trials comparing HBOT and normobaric $\mathrm{O}_{2}$ therapy. Those studies were examined in a systematic review, and, to date, there has been no conclusive evidence that HBOT reduces the incidence of neurological sequelae; in addition to have yielded conflicting results, 
those studies are highly heterogeneous in terms of design, methodology, protocol, study population, and analysis. ${ }^{(35,38)}$

Data regarding the prognosis of patients with CO poisoning are inconclusive and contradictory. Approximately 30\% of all patients with severe CO poisoning can have a fatal outcome. Indicators of poor prognosis include altered state of consciousness at presentation, advanced age, underlying cardiovascular disease, metabolic acidosis, and structural abnormalities on CT scans or magnetic resonance images. ${ }^{(29)}$

\section{HCN poisoning}

A highly volatile compound, $\mathrm{HCN}$ is formed by the incomplete combustion of carbonaceous and nitrogenous materials during a fire, including cotton, silk, wood, paper, plastics, sponges, acrylics, and synthetic polymers in general..$^{(4,39)}$ In addition, the recycling of pyrolysis products in enclosed spaces increases the rate of HCN formation, and the lack of ventilation in the environment can increase that rate by up to 10 times. $^{(4)}$

Notable for its ability to bind to iron ions, $\mathrm{HCN}$ is carried through the bloodstream by red blood cells. In the intracellular environment, HCN binds to the enzyme cytochrome c oxidase a, completely blocking the respiratory cycle and, consequently, the formation of ATP. Therefore, profound lactic acidosis occurs, death occurring within minutes after exposure to large doses. ${ }^{(3,4,40)}$

After being absorbed, HCN rapidly disappears from the bloodstream, its alpha half-life ranging from $1 \mathrm{~h}$ to $3 \mathrm{~h}$, its beta half-life being $44 \mathrm{~h}$, and its peak concentration being difficult to measure. ${ }^{(3)}$ Therefore, a blood sample should be obtained as early as possible, even while still at the scene of the accident, and treatment should be initiated before laboratory test results are known, the results being released within $2 \mathrm{~h}$, on average.

The diagnosis of $\mathrm{HCN}$ poisoning remains a challenge and is essentially based on a high clinical suspicion. The initial manifestations reflect respiratory and neurological stimulation resulting from the blockade of cellular respiration, including hyperventilation, headache, nausea, vomiting, palpitations, and anxiety. Subsequently, convulsions, bradycardia, and hypotension occur, culminating in respiratory arrest and cardiovascular collapse. ${ }^{(4,40)}$ Because very few patients survive, reports of neurological sequelae are rare. However, mild CO poisoning is recognized as a cause of permanent neurological injury, ranging from extrapyramidal manifestations of varying intensity to a persistent vegetative state progressing over the years. ${ }^{(40)}$

Serum HCN concentrations above $0.5 \mathrm{mg} / \mathrm{L}$ are related to acute poisoning. ${ }^{(39)}$ There is some correlation between serum HCN levels and symptom severity; in general, serum levels of $0.5-1 \mathrm{mg} / \mathrm{L}$ are mild, serum levels of $2-3 \mathrm{mg} / \mathrm{L}$ are moderate, and serum levels above $3 \mathrm{mg} / \mathrm{L}$ are lethal..$^{(4)}$

Plasma lactate concentrations above $90 \mathrm{mg} / \mathrm{dL}$ or $10 \mathrm{mmol} / \mathrm{L}$ correlate with $\mathrm{HCN}$ poisoning. ${ }^{(3,4)} \mathrm{A}$ small case series of patients with HCN poisoning unrelated to smoke inhalation showed that serum lactate levels above $8 \mathrm{mmol} / \mathrm{L}$ have a sensitivity of $94 \%$, a specificity of $74 \%$, a positive predictive value of $98 \%$, and a negative predictive value of 98\% for predicting serum HCN levels $>1$ $\mathrm{mg} / \mathrm{L} \cdot{ }^{(41)} \mathrm{A}$ reduced arterial-venous $\mathrm{O}_{2}$ difference is also observed, being generally lower than 10 $\mathrm{mmHg}$, which explains the absence of cyanosis. Because there is no correlation between $\mathrm{COHb}$ levels and HCN levels, it is impossible to predict concomitant poisoning. ${ }^{(4)}$

For decades, a cyanide antidote kit was available in the USA and consisted of a combination of three drugs, namely inhaled amyl nitrite, intravenous sodium nitrite (both drugs being capable of generating methemoglobin, which diverts HCN from the mitochondrial cytochrome), and intravenous sodium thiosulfate for $30 \mathrm{~min}$ (which binds to free HCN via the enzyme rhodanese and forms thiocyanate, which is cleared by the kidneys). The kit has a slow onset of action and causes hypotension, as well as inducing methemoglobinemia, which can be harmful to smoke inhalation victims with suspected CO poisoning. ${ }^{(39)}$

According to a European expert consensus published in $2012^{(4)}$ and a North American review of prehospital care, ${ }^{(3)}$ the drug of choice for the treatment of patients with suspected HCN poisoning is hydroxocobalamin, a drug that has recently been made available by the Ministry of Health, which binds to HCN to form cyanocobalamin, which is excreted in urine. Hydroxocobalamin is a drug with a rapid onset of action, reaching therapeutic levels in the cerebrospinal fluid within approximately $30 \mathrm{~min}$ after administration. Minor adverse effects have been reported, including hypertension, reflex bradycardia, and urticaria-like rashes, as well as 
reddish skin and urine. ${ }^{(40)} \mathrm{In}$ a prospective cohort study, the preemptive use of hydroxocobalamin $(5 \mathrm{~g}$ diluted in $100 \mathrm{~mL}$ of distilled water and infused for 15-20 min, with the possibility of repeating the same dose in cases of coma or persistent hemodynamic instability) resulted in the survival of $67 \%$ of the patients with HCN poisoning from smoke inhalation. ${ }^{(42)}$

The role of HBOT in the adjunctive treatment of concomitant $\mathrm{CO}$ and $\mathrm{HCN}$ poisoning is controversial. The physiological rationale is based on a greater induction of nitric oxide formation in the bloodstream, nitric oxide competing with $\mathrm{HCN}$ for the binding to the enzyme cytochrome $\mathrm{c}$ oxidase a. ${ }^{(40)}$ A quasi-experimental study showed no reduction in blood concentrations of $\mathrm{HCN}$ after HBOT in SIl victims. ${ }^{(43)}$

It is recommended that all Sll victims presenting with a decreased level of consciousness (Glasgow coma scale score $\leq 13$ ) or signs of hemodynamic instability and respiratory failure be empirically treated with hydroxocobalamin in a prehospital environment. In cases of cardiac arrest attributed to $\mathrm{HCN}$ poisoning, it is possible to administer a double dose immediately or repeat the standard dose. When referred to the emergency room, patients for whom the antidote was not initially indicated but who show elevated levels of lactate during a 2-h observation period should also receive the antidote. ${ }^{(4)}$ Patients diagnosed with brain death due to HCN poisoning are candidates for organ donation. ${ }^{(3)}$

\section{Final considerations}

Enclosed-space fires should raise the suspicion of S1l associated with loss of consciousness, facial burns, and large TBSA burns. Treatment is basically supportive, consisting of immediate $\mathrm{O}_{2}$ therapy, rapid administration of an antidote, and protective mechanical ventilation. The use of inhaled heparin in victims of thermal injury is recommended by some experts. In such patients, the use of HBOT is highly controversial, as is the use of additional ventilation modes. In addition to immediate management, individuals with S1l should be extubated as soon as possible, and attention should be paid to the possibility of early tracheostomy.

\section{References}

1. Ryan CM, Schoenfeld DA, Thorpe WP, Sheridan RL, Cassem EH, Tompkins RG. Objective estimates of the probability of death from burn injuries. N Engl J Med. 1998;338(6):362-6. http://dx.doi.org/10.1056/ NEJM199802053380604 PMid:9449729

2. Barillo DJ. Diagnosis and treatment of cyanide toxicity. J Burn Care Res. 2009;30(1):148-52. http://dx.doi. org/10.1097/BCR.0b013e3181923b91 PMid:19060738

3. O'Brien DJ, Walsh DW, Terriff CM, Hall AH. Empiric management of cyanide toxicity associated with smoke inhalation. Prehosp Disaster Med. 2011;26(5):37482. http://dx.doi.org/10.1017/S1049023X11006625 PMid:22336184

4. Anseeuw K, Delvau N, Burillo-Putze G, De laco F, Geldner G, Holmström P, et al. Cyanide poisoning by fire smoke inhalation: a European expert consensus. Eur J Emerg Med. 2013;20(1):2-9. http://dx.doi.org/10.1097/ MEJ.0b013e328357170b PMid:22828651

5. Cancio LC. Airway management and smoke inhalation injury in the burn patient. Clin Plast Surg. 2009;36(4):55567. http://dx.doi.org/10.1016/j.cps.2009.05.013 PMid:19793551

6. Mlcak RP, Suman OE, Herndon DN. Respiratory management of inhalation injury. Burns. 2007;33(1):213. http://dx.doi.org/10.1016/j.burns.2006.07.007 PMid:17223484

7. Madnani DD, Steele NP, de Vries E. Factors that predict the need for intubation in patients with smoke inhalation injury. Ear Nose Throat J. 2006;85(4):27880. PMid:16696366

8. Mosier MJ, Pham TN, Park DR, Simmons J, Klein MB, Gibran NS. Predictive value of bronchoscopy in assessing the severity of inhalation injury. J Burn Care Res. 2012;33(1):65-73. http://dx.doi.org/10.1097/ BCR.0b013e318234d92f PMid:21941194

9. Albright JM, Davis CS, Bird MD, Ramirez L, Kim H, Burnham EL, et al. The acute pulmonary inflammatory response to the graded severity of smoke inhalation injury. Crit Care Med. 2012;40(4):1113-21. http://dx.doi. org/10.1097/CCM.0b013e3182374a67 PMid:22067627 PMCid:3290689

10. Endorf FW, Gamelli RL. Inhalation injury, pulmonary perturbations, and fluid resuscitation. J Burn Care Res. 2007;28(1):80-3. http://dx.doi.org/10.1097/ BCR.0B013E31802C889F PMid:17211205

11. Oh JS, Chung KK, Allen A, Batchinsky Al, Huzar T, King BT, et al. Admission chest CT complements fiberoptic bronchoscopy in prediction of adverse outcomes in thermally injured patients. J Burn Care Res. 2012;33(4):532-8. http://dx.doi.org/10.1097/ BCR.0b013e318237455f PMid:22210063

12. Carr JA, Phillips BD, Bowling WM. The utility of bronchoscopy after inhalation injury complicated by pneumonia in burn patients: results from the National Burn Repository. J Burn Care Res. 2009;30(6):967-74. PMid:19826269

13. Latenser BA. Critical care of the burn patient: the first 48 hours. Crit Care Med. 2009;37(10):2819-26. http://dx.doi. org/10.1097/CCM.0b013e3181b3a08f PMid:19707133

14. Dai NT, Chen TM, Cheng TY, Chen SL, Chen SG, Chou GH, et al. The comparison of early fluid therapy in extensive flame burns between inhalation and noninhalation injuries. Burns. 1998;24(7):671-5. http://dx.doi.org/10.1016/ S0305-4179(98)00092-8

15. Cartotto R, Walia G, Ellis S, Fowler R. Oscillation after inhalation: high frequency oscillatory ventilation in burn patients with the acute respiratory distress syndrome 
and co-existing smoke inhalation injury. J Burn Care Res. 2009;30(1):119-27. http://dx.doi.org/10.1097/ BCR.0b013e3181920fe6 PMid:19060765

16. Chung KK, Wolf SE, Renz EM, Allan PF, Aden JK, Merrill GA, et al. High-frequency percussive ventilation and low tidal volume ventilation in burns: a randomized controlled trial. Crit Care Med. 2010;38(10):1970-7. PMid:20639746

17. Hale DF, Cannon JW, Batchinsky Al, Cancio LC, Aden JK, White CE, et al. Prone positioning improves oxygenation in adult burn patients with severe acute respiratory distress syndrome. J Trauma Acute Care Surg. 2012;72(6):1634-9. http://dx.doi.org/10.1097/ TA.0b013e318247cd4f PMid:22695433

18. Asmussen S, Maybauer DM, Fraser JF, Jennings K, George S, Keiralla A, et al. Extracorporeal membrane oxygenation in burn and smoke inhalation injury. Burns. 2013;39(3):429-35. http://dx.doi.org/10.1016/j. burns.2012.08.006 PMid:23062623

19. Kabalak AA, Yastı AC. Management of inhalation injury and respiratory complications in Burns Intensive Care Unit. Ulus Travma Acil Cerrahi Derg. 2012;18(4):333-8. http:// dx.doi.org/10.5505/tjtes.2012.09735 PMid:23139001

20. Holt J, Saffle JR, Morris SE, Cochran A. Use of inhaled heparin/N-acetylcysteine in inhalation injury: does it help? J Burn Care Res. 2008;29(1):192-5. PMid:18182921

21. Miller AC, Rivero A, Ziad S, Smith DJ, Elamin EM. Influence of nebulized unfractionated heparin and $\mathrm{N}$-acetylcysteine in acute lung injury after smoke inhalation injury. J Burn Care Res. 2009;30(2):249-56. http://dx.doi.org/10.1097/ BCR.0b013e318198a268 PMid:19165116

22. Tuinman PR, Dixon B, Levi M, Juffermans NP, Schultz MJ. Nebulized anticoagulants for acute lung injury - a systematic review of preclinical and clinical investigations. Crit Care. 2012;16(2):R70. http://dx.doi.org/10.1186/ cc11325 PMid:22546487

23. Edelman DA, Khan N, Kempf K, White MT. Pneumonia after inhalation injury. J Burn Care Res. 2007;28(2):241-6. http://dx.doi.org/10.1097/BCR.0B013E318031D049 PMid:17351439

24. Chacko J, Jahan N, Brar G, Moorthy R. Isolated inhalational injury: Clinical course and outcomes in a multidisciplinary intensive care unit. Indian J Crit Care Med. 2012;16(2):93-9. http://dx.doi.org/10.4103/09725229.99120 PMid:22988364 PMCid:3439785

25. Lin CC, Liem AA, Wu CK, Wu YF, Yang JY, Feng CH. Severity score for predicting pneumonia in inhalation injury patients. Burns. 2012;38(2):203-7. http://dx.doi. org/10.1016/j.burns.2011.08.010 PMid:21963078

26. Durbin CG Jr, Perkins MP, Moores LK. Should tracheostomy be performed as early as 72 hours in patients requiring prolonged mechanical ventilation? Respir Care. 2010;55(1):76-87. PMid:20040126

27. Cha Sl, Kim CH, Lee JH, Park JY, Jung TH, Choi Wl, et al. Isolated smoke inhalation injuries: acute respiratory dysfunction, clinical outcomes, and short-term evolution of pulmonary functions with the effects of steroids. Burns. 2007;33(2):200-8. http://dx.doi.org/10.1016/j. burns.2006.07.017 PMid:17169496

28. Weaver LK. Carbon monoxide poisoning. Crit Care Clin. 1999;15(2):297-317, viii. http://dx.doi.org/10.1016/ S0749-0704(05)70056-7

29. Varon J, Marik PE, Fromm RE Jr, Gueler A. Carbon monoxide poisoning: a review for clinicians. J Emerg
Med. 1999;17(1):87-93. http://dx.doi.org/10.1016/ S0736-4679(98)00128-0

30. McCall JE, Cahill TJ. Respiratory care of the burn patient. J Burn Care Rehabil. 2005;26(3):200-6. PMid:15879741

31. Ernst A, Zibrak JD. Carbon monoxide poisoning. N Engl J Med. 1998;339(22):1603-8. http://dx.doi.org/10.1056/ NEJM199811263392206 PMid:9828249

32. Raub JA, Mathieu-Nolf M, Hampson NB, Thom SR. Carbon monoxide poisoning--a public health perspective. Toxicology. 2000;145(1):1-14. http://dx.doi.org/10.1016/ S0300-483X(99)00217-6

33. Kao LW, Na-agas KA. Carbon monoxide poisoning. Emerg Med Clin North Am. 2004;22(4):985-1018. http://dx.doi. org/10.1016/j.emc.2004.05.003 PMid:15474779

34. Souza R, Jardim C, Salge JM, Carvalho CR. Lesão por inalação de fumaça. J Bras Pneumol. 2004;30(6):557-65. http://dx.doi.org/10.1590/S1806-37132004000600011

35. Kealey GP. Carbon monoxide toxicity. J Burn Care Res. 2009;30(1):146-7. http://dx.doi.org/10.1097/ BCR.0b013e3181923b81 PMid:19060737

36. Henry CR, Satran D, Lindgren B, Adkinson C, Nicholson $\mathrm{Cl}$, Henry TD. Myocardial injury and long-term mortality following moderate to severe carbon monoxide poisoning. JAMA. 2006;295(4):398-402. http://dx.doi.org/10.1001/ jama.295.4.398 PMid:16434630

37. Satran D, Henry CR, Adkinson C, Nicholson Cl, Bracha Y, Henry TD. Cardiovascular manifestations of moderate to severe carbon monoxide poisoning. J Am Coll Cardiol. 2005;45(9):1513-6. http://dx.doi.org/10.1016/j. jacc.2005.01.044 PMid:15862427

38. Buckley NA, Juurlink DN, lsbister G, Bennett MH, Lavonas EJ. Hyperbaric oxygen for carbon monoxide poisoning. Cochrane Database Syst Rev. 2011;(4):CD002041. PMid:21491385

39. Hamel J. A review of acute cyanide poisoning with a treatment update. Crit Care Nurse. 2011;31(1):7281; quiz 82. http://dx.doi.org/10.4037/ccn2011799 PMid:21285466

40. Lawson-Smith P, Jansen EC, Hyldegaard O. Cyanide intoxication as part of smoke inhalation--a review on diagnosis and treatment from the emergency perspective. Scand J Trauma Resusc Emerg Med. 2011;19:14. http:// dx.doi.org/10.1186/1757-7241-19-14 PMid:21371322 PMCid:3058018

41. Baud FJ, Borron SW, Mégarbane B, Trout H, Lapostolle F, Vicaut E, et al. Value of lactic acidosis in the assessment of the severity of acute cyanide poisoning. Crit Care Med. 2002;30(9):2044-50. http://dx.doi.org/10.1097/00003246200209000-00015 PMid:12352039

42. Borron SW, Baud FJ, Barriot P, Imbert M, Bismuth C. Prospective study of hydroxocobalamin for acute cyanide poisoning in smoke inhalation. Ann Emerg Med. 2007;49(6):794-801, 801.e1-2.

43. Lawson-Smith P, Jansen EC, Hilsted L, Hyldegaard 0 . Effect of hyperbaric oxygen therapy on whole blood cyanide concentrations in carbon monoxide intoxicated patients from fire accidents. Scand J Trauma Resusc Emerg Med. 2010;18:32. http://dx.doi.org/10.1186/17577241-18-32 PMid:20550698 PMCid:2894003 


\section{About the authors}

Ana Carolina Peçanha Antonio

Intensivist. Hospital Mãe de Deus, Porto Alegre, Brazil.

Priscylla Souza Castro

Intensivist. Hospital Mãe de Deus, Porto Alegre, Brazil.

Luiz Octavio Freire

Manager. Pulmonology Institute, Hospital Mãe de Deus, Porto Alegre, Brazil. 